УДК 903

https://doi.org/10.24852/2587-6112.2021.1.340.354

\title{
ОБЩИЕ СВЕДЕНИЯ О НАУЧНОЙ ДЕЯТЕЛЬНОСТИ \\ ИНСТИТУТА АРХЕОЛОГИИ ИМЕНИ А.Х. ХАЛИКОВА АКАДЕМИИ НАУК РЕСПУБЛИКИ ТАТАРСТАНА В 2020 ГОДУ
}

\author{
(ㄷ 2021 г. А.Г. Ситдиков, Р.Р. Саттаров, Г.Ш. Асылгараева
}

В статье приводятся основные итоги научной деятельности Института археологии им А.Х. Халикова Академии наук Республики Татарстан в 2020 году. Научно-исследовательская деятельность института осуществлялась по четырем фундаментальным и трем прикладным направлениям. В 2020 году обследованы значительные площади территории Республики Татарстан на наличие объектов культурного наследия. В рамках выполнения государственной программы Республики Татарстан «Сохранение национальной идентичности татарского народа (2014-2021 годы)» проведены работы в Астраханской, Волгоградской, Нижегородской, Рязанской, Саратовской и Ульяновской областях и Республике Калмыкия. Ежегодно Институтом издаются два академических рецензируемых журнала: «Поволжская археология» и «Археология Евразийских степей». Важным событием 2020 года стало открытие на базе Академии наук Республики Татарстан диссертационного совета по защите кандидатских и докторских диссертаций по направлению «История и археология».

Ключевые слова: Институт археологии им. А.Х. Халикова АН РТ, археология, фундаментальные научные исследования, прикладные научные исследования, конференции, публикации, выставки, охрана археологического наследия, госпрограмма..

\section{GENERAL INFORMATION ABOUT THE SCIENTIFIC ACTIVITIES OF THE INSTITUTE OF ARCHAEOLOGY NAMED AFTER A. KH. KHALIKOV OF THE TATARSTAN ACADEMY OF SCIENCES IN 2020}

\author{
A. G. Sitdikov, R. R. Sattarov, G. Sh. Asylgaraeva
}

The paper features the main results of scientific activities by the Institute of Archaeology named after A. Kh. Khalikov of the Tatarstan Academy of Sciences in 2020. The research activities of the Institute were carried out in four fundamental and three applied fields. Significant territories of the Republic of Tatarstan were studied to identify cultural heritage sites in 2020. In the framework of the implementation of the state program of the Republic of Tatarstan "Preservation of the National Identity of the Tatar people (2014-2021)", work was carried out in the Astrakhan, Volgograd, Nizhny Novgorod, Ryazan, Saratov and Ulyanovsk Oblasts and the Republic of Kalmykia. The Institute annually publishes two academic peer-reviewed journals: The Volga River Region Archaeology and Archaeology of the Eurasian Steppes. An important event in 2020 was the opening of a dissertation council for the defense of candidate's and doctoral theses in the field of "History and Archaeology" on the basis of the Tatarstan Academy of Sciences.

Keywords: Institute of Archaeology named after A. Kh. Khalikov of the Academy of Sciences of the Republic of Tatarstan, archaeology, fundamental research, applied research, conferences, publications, exhibitions, protection of archaeological heritage, state program.

Институт археологии им. А.Х. Халикова Академии наук Республики Татарстан (далее - Институт) является одним из ведущих археологических академических институтов на территории Европейской части Российской Федерации Результаты многолетних работ Института охватывают широкий спектр фундаментальных и прикладных исследований (Ситдиков и др. 2015, с. 241-259; Ситдиков, Каримов, 2016, с. 276-290; Ситдиков, Каримов, 2017, с. 330-343; Ситдиков и др.,2018, с. 342-354; Бочаров и др., 2020, c.196-216).
В 2020 г. научно-исследовательская и научно-организационная деятельность Института осуществлялась согласно Государственному заданию, «Стратегии развития Института археологии им. А.Х. Халикова АН РТ на 2019-2021 гг.» и целевым государственным программам. Основным источником финансирования в 2020 г. был бюджет АН РТ, на проведение дополнительных научных исследований были привлечены внебюджетные средства, полученные в ходе реализации археологических охранно-спасательных работ. Также финансирование научно-исследова- 
тельской работы осуществлялось в виде грантов фондов РФФИ, «Возрождение» и «История Отечества».

Институт вел научные исследования по нескольким фундаментальным направлениям: «Исследование преемственности и трансформации археологических культур Волго-Уральского региона», «Изучение народов ВолгоУральского региона в системе средневековых цивилизаций Евразии. Великий шелковый путь», «Исследования по археометрии», «Разработка многотомной «Археологии Волго-Уральского региона». В рамках этих направлений сотрудниками Института проводились исследования по 82 темам. В отчетный период опубликовано 6 монографий, учебных пособий, 117 статей и подготовлено 40 научных отчетов (список публикаций за 2020 г. приведен в конце статьи).

Крупным научным событием 2020 г. стало издание двухтомной академической монографии: «Каратунский клад джучидских монет XIV века» под авторством Г.А. Федорова-Давыдова и Д.Г. Мухаметшина (Т. 1. 384 с.; Том II. 487 с.) (рис. 1). Каратунский клад монет, найденный в 1986 г. в Апастовском районе Республики Татарстан, - самый большой из известных науке кладов золотоордынских (джучидских) монет в Европейской части России. В кладе представлены монеты почти всех золотоордынских ханов XIV в., имеются также подражания золотоордынским дирхемам, монеты иранской династии Джалаиридов, монеты Тимура и его ханов, несколько монет русских княжеств, а также по одной монете Трапезундской империи и Галицкой Руси (Федоров-Давыдов, Мухаметшин, 2020, T. 1, T. 2).

Институтом было проведено 5 международных научных конференций. Проведенные мероприятия были не только крупными дискуссионными площадками в сфере археологических изысканий, но и стали показателем значительно расширившегося исследовательского диапазона Института по проблемам изучения и сохранения историко-культурного наследия в целом, а также в сфере междисциплинарных исследований. Большой научный и общественный резонанс получил Международный научный симпозиум «Археогеномика, шаг за шагом к пониманию истории древних домашних животных в Европе» (г. Казань, Болгар, 25-28 февраля 2020 г.), который был организован совместно с Институтом проблем экологии и недропользования Академии наук Республики Татарстан. Во время работы симпозиума были заслушаны доклады ведущих ученых из главных научных подразделений в области археогеномики: Великобритании, Дании, Франции, Финляндии и России, обсуждены актуальные вопросы генетических исследований древних популяций различных домашних животных от неолита до средневековья Европы (рис. 2).

В 2020 году была продолжена работа по созданию семитомной академической «Археологии Волго-Уральского региона», являющейся фундаментальным направлением научно-исследовательской деятельности Института, всех его структурных подразделений и научных сотрудников. В отчетном году активно происходило написание авторских разделов и подготовка иллюстративного материала. Исследователями были систематизированы архивные данные и публикации, уточнены историографические и фактологические сведения по ряду памятников, необходимые при подготовке соответствующих разделов томов. Проведено обобщение имеющихся к настоящему времени данных и материалов с целью выявления культурно-хронологических маркеров при подготовке разделов многотомника. Кроме того, научными сотрудниками Института проведено рецензирование присланных иногородними членами авторских коллективов томов рукописей разделов.

Основными направлениями прикладных исследований в 2020 г. стали: «Прове-

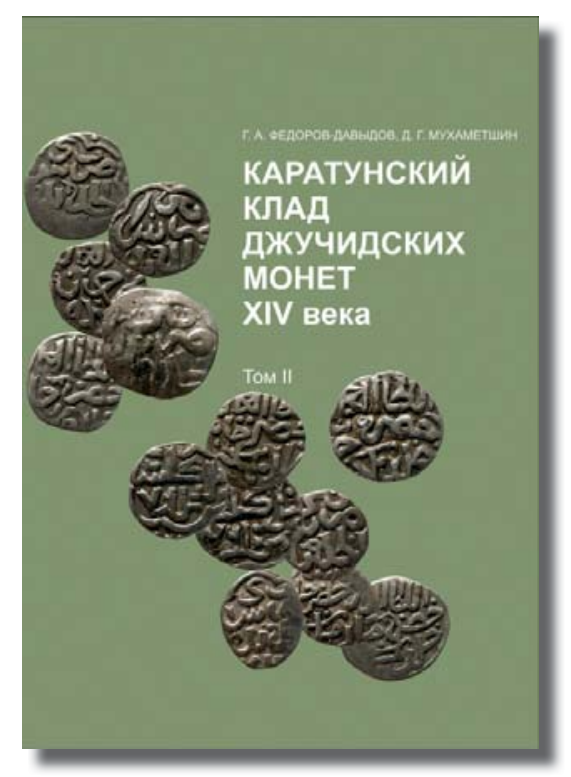

Рис. 1. Обложка 2 тома монографии «Каратунский клад джучидских монет XIV века»

Fig. 1. Cover of the 2nd volume of the monograph "Karatun Hoard of 14th century Juchid Coins" 


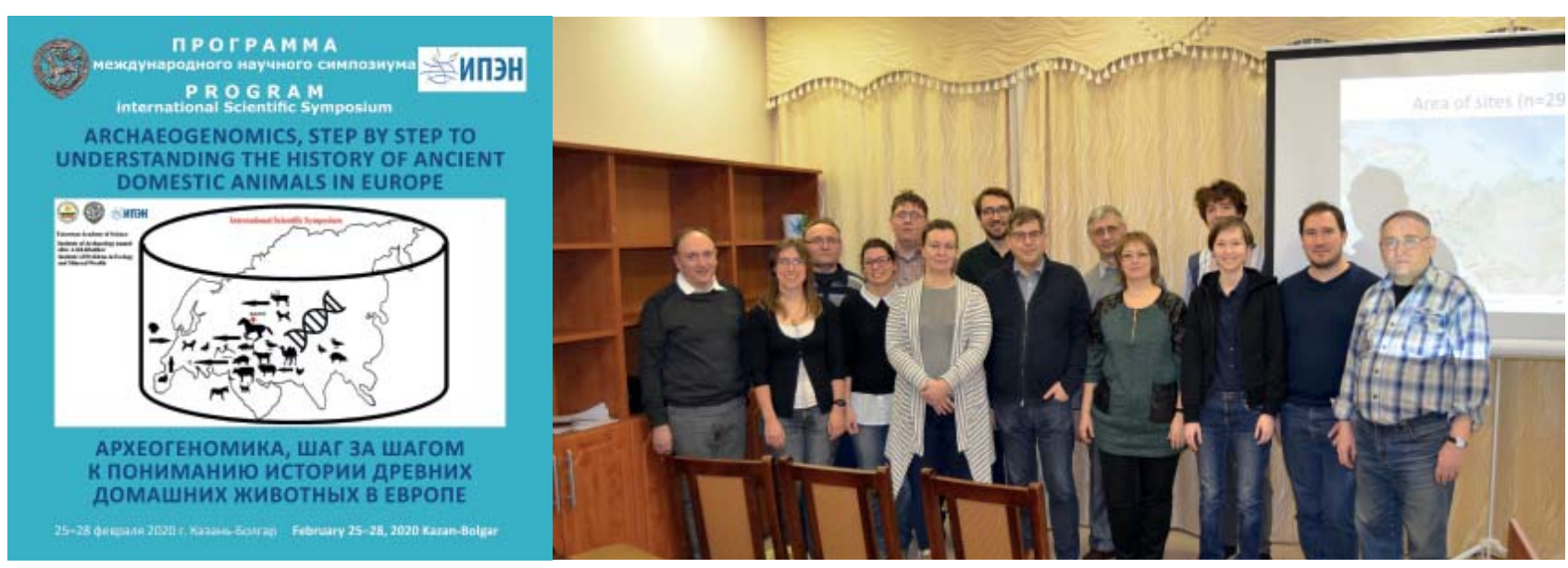

Рис. 2. Участники конференции «Археогеномика, шаг за шагом к пониманию истории древних домашних животных в Европе»

Fig. 2. Participants of the conference "ArchaeoGenomics, Step by Step to Understanding the History of Ancient Domestic Animals in Europe"

дение исследований в области археологии. Формирование фондов музея археологии РТ», «Пополнение геопортала «Культурное наследие Татарстана и татарского народа», «Обеспечение сохранения и использования объектов культурного наследия. Обработка предметов археологии, антропологии, музейных коллекций, научных и музейных фондов. Реставрация и консервация предметов археологии».

Динамика пополнения музейного собрания имеет устойчивую положительную тенденцию. В 2020 г. продолжилась научная и учетная обработка археологических коллекций, находящихся на дофондовом хранении Музея археологии РТ (далее - МА РТ) с общим количеством около 3100 коллекций (около 350000 ед. хранения). Подготовлены к передаче в собрание МА РТ (на временном хранении до рассмотрения на ЭФЗК) 25554 предмета. Необходимо отметить, что такого количества поступлений уникальных артефактов археологического и историко-культурного насле- дия не отмечено в других музеях Татарстана. На 2020 г. фонды МА РТ включают в себя 69295 ед. хранения (рис. 3).

В целях сохранения, изучения, музеефикации и пропаганды научного археологического наследия Татарстана были продолжены работы по научно-технической обработке научного фонда, в том числе личных фондов ученых-археологов. На конец отчетного года в методическом кабинете учтено 15731 научных изданий. В научном фонде всего 3174 единицы хранения. В отчетном году продолжалась экспозиционно-выставочная деятельность. Проведено 10 экспозиций и выставок.

В феврале 2020 г. президент Республики Татарстан Рустам Минниханов посетил MA РТ, расположенный на территории Казанского Кремля, где была представлена временная выставка (рис. 4). Сотрудники музея провели для Рустама Минниханова экскурсию по помещениям музея, рассказали об основных направлениях деятельности специалистов. На базе МА РТ ведется рабо-

Рис. 3. Фонды Музея археологии РТ.

Fig. 3. Funds of the Museum of Archaeology of the Republic of Tatarstan.
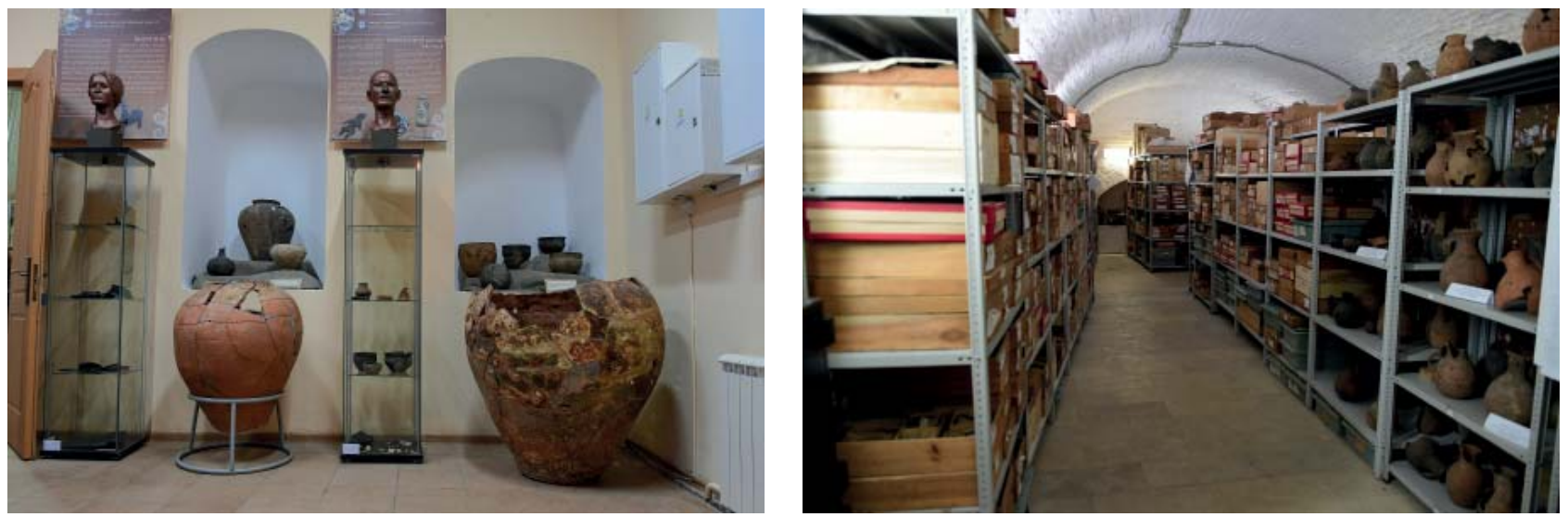


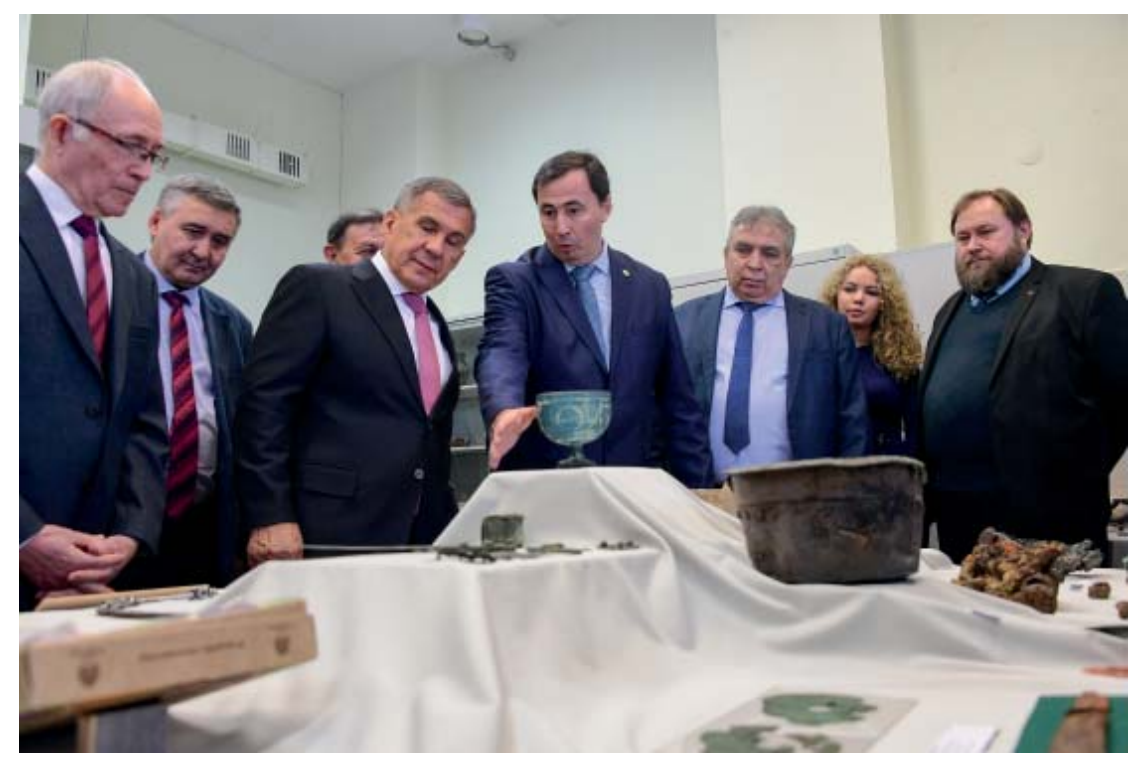

Рис. 4. Президент Татарстана Рустам Минниханов в Музее археологии ИА АН РТ

Fig. 4. President of Tatarstan Rustam Minnikhanov at the Museum of Archaeology of the Institute of Archaeology of the Tatarstan Academy of Sciences

та по созданию нового инструмента сохранения наследия - депозитария как основного фондохранилища археологических коллекций.

9 июля 2020 года в Галерее современного искусства ГМИИ РТ состоялось открытие выставки, организованной Государственным музеем изобразительных искусств Республики Татарстан совместно с Институтом в рамках многочастного выставочного проекта, посвященного 100-летию ТАССР. На выставке представлены археологические коллекции, добытые при раскопках раннебулгарского некрополя IX - первой половины X вв. у с. Танкеевка Спасского района РТ, Билярского городища и Куркульского селища X - начала XIII вв. (Алексеевский район РТ), Джукетауского городища конца X-XIV вв. (Чистопольский район РТ), Селитренного городища XIV вв. (Сарай-Бату, Астраханская область), Казанского кремля и городского посада (слои ханского и русского времени), а также других археологических памятников Республики Татарстан (рис. 5).

С 30 сентября по 2 октября 2020 года в Казани прошел XIX Всероссийский съезд органов охраны памятников истории и культуры, приуроченный к 100-летию образования ТАССР. В рамках форума МА РТ была организована выставка, посвященная проблеме сохранения объектов культурного наследия, в частности, реставрации и консервации музейных предметов из собрания музея. На выставке были представлены комплексы из металла, керамики и органических материа- лов до и после реставрации, охватывающие хронологические рамки от раннего Средневековья до Нового времени с таких памятников, как Куркульское I селище, Старокуйбышевский комплекс памятников, Танкеевский и Такталачукский могильники, Казанский кремль и г. Казань, Свияжска (рис. 5). Открытие выставок сопровождалось информацией в средствах массовой информации, ТВ и сети Интернет.

Актуальным направлением научно-исследовательской деятельности Института является создание и постоянное наполнение новыми данными геоинформационного портала «Культурное наследие Татарстана и татарского народа», который является цифровым пространством, созданным для интеграции гуманитарного знания. Он позволяет хранить и анализировать научные исследования и архивные материалы о языке, археологии и истории, материальной и духовной культуре народов Татарстана и Поволжья. Средства портала выполняют функцию обеспечения взаимодействия государственных институтов, экспертных групп и широкой общественности в области культурного наследия. В 2020 г. в базу геоданных внесено более 800 отчетов, 160 статей, 600 фотоматериалов и других данных о культурном наследии Татарстана и татарского народа. На данный момент всего учтено 16377 памятников археологии, 1295 архитектурных памятников, проведено 2716 радиоуглеродных датировок, внесено 1035 отчетов об археологических исследованиях, 2024 публикации, 1650 персоналий 


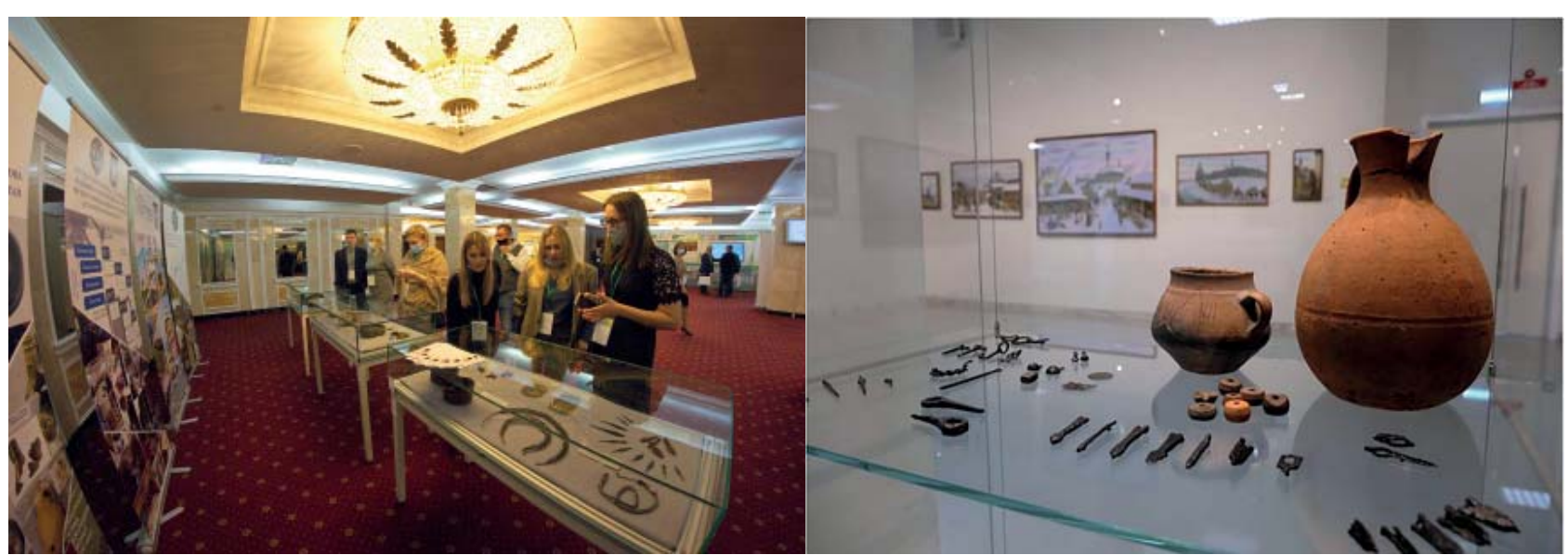

Рис. 5. Археологическая выставка в Государственном музее изобразительных искусств РТ и на XIX Всероссийском съезде органов охраны памятников истории и культуры

Fig. 5. Archaeological exhibition at the State Museum of Fine Arts of the Republic of Tatarstan and the 19th All-Russian Congress of Historical and Cultural Monument Protection Bodies

и т.д. (http://archtat.ru/kulturnoye naslediye tatarstana/).

В 2020 г. Институтом осуществлялась активная межрегиональная и международная деятельность в рамках реализации Государственной программы Республики Татарстан «Сохранение национальной идентичности татарского народа (2014-2024 годы)», направленной на проведение историко-археологических исследований средневековых городов и изучение историкокультурного тюрко-татарского наследия за пределами Республики Татарстан. В 2020 году Институтом проведены работы на городище Увек и поселении Песочное XIII-XIV вв. (Саратовская область), городище Башанта VII-IX вв. (Республика Калмыкия), в городе Касимов XIII-XIX вв. (Рязанская область), городище Курмыш XIV-XVI вв. (Нижегородская область), Царевском городище XIV вв. (Волгоградская область), комплексе мавзолеев Лапас XIII-XV вв. (?) и могильнике Посоль- ский, содержащем материалы III тыс. до н.э. и с IV до н.э. по XIII в. н.э. (Астраханская область), Красносюндюковском городище XI-XIII вв. (Ульяновская область) и др. (рис. 6).

Актуальным направлением деятельности Института является организация и проведение комплексных охранно-спасательных археологических исследований. В отчетном году были обследованы значительные площади территории Республики Татарстан на наличие объектов культурного наследия (более 500 га). Площадь археологических раскопок составила 2733,7 кв.м, археологических наблюдений - 7332,1 кв.м. Всего для проведения археологических исследований Институтом в Министерстве культуры РФ было получено 23 открытых листа (разрешений) на проведение археологических работ. Проведенные работы являются важной составляющей формирования целостной системы сохранения историко-культурного наследия и его эффектив-

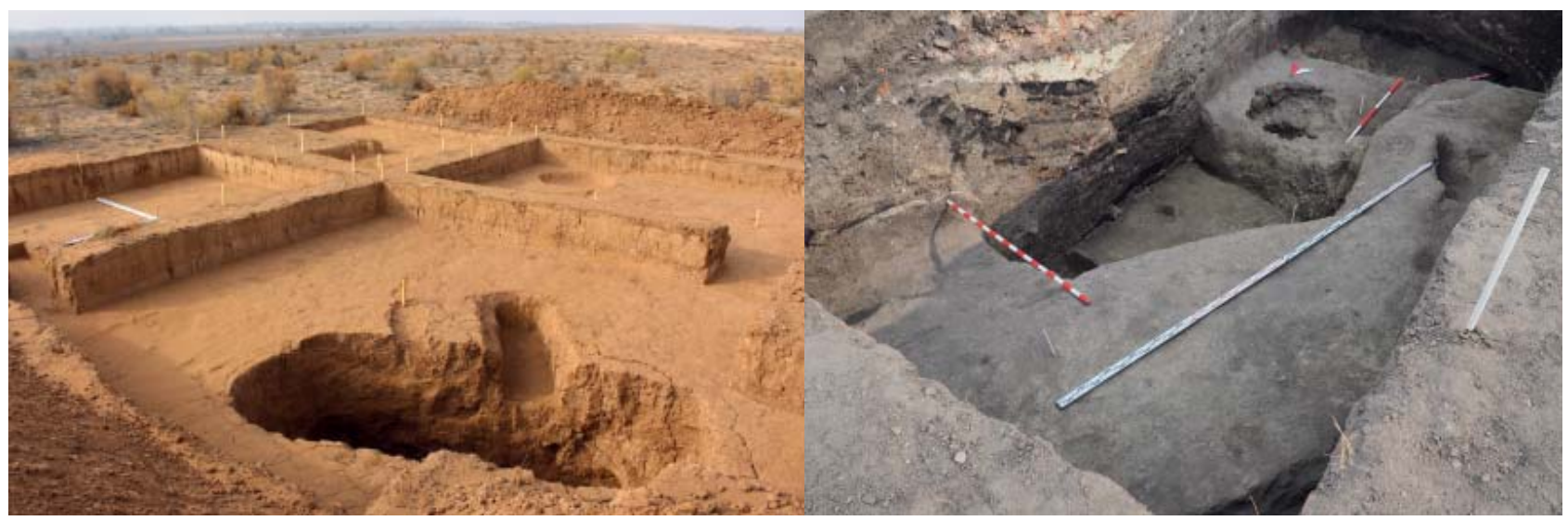

Рис. 6. Археологические исследования Института археологии им. А.Х. Халикова за предедами Республики Татарстан: могильник Посольский (Астраханская обл.), годище Увек (Саратовская область).

Fig. 6. Archaeological studies of the Institute of Archaeology named after A. Kh. Khalikov outside the Republic of Tatarstan: Posolsky burial ground (Astrakhan Oblast), Uvek settlement (Saratov Oblast). 


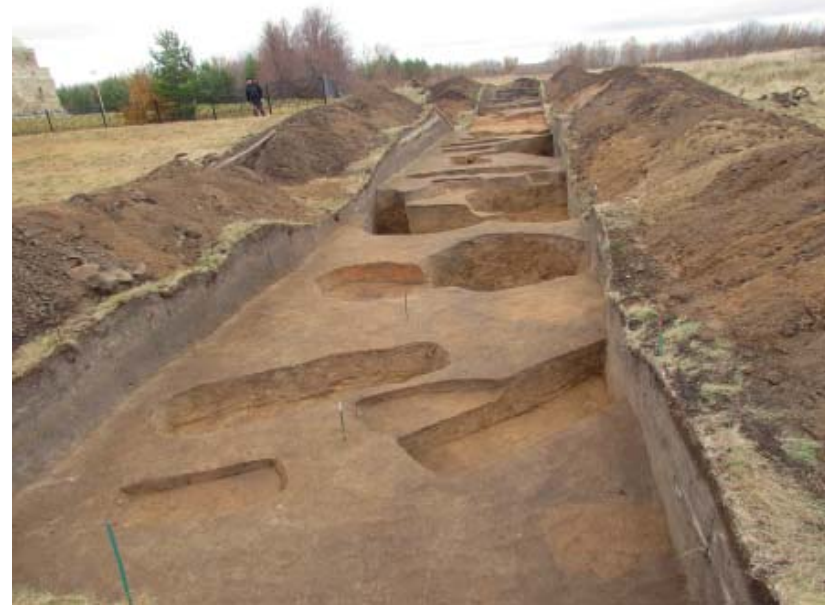

ного использования, включения уникальных памятников и исторических территорий в программы российского и международного туризма (рис. 7).

В отчетном году на базе Академии наук Республики Татарстан был открыт диссертационный совет по защите кандидатских и докторских диссертаций по направлению «История и археология», что является важным событием в рамках подготовки кадров высшей научной квалификации. На данный момент в аспирантуре Института проходят обучение три человека. Темы диссертационных работ аспирантов посвящены актуальным проблемам истории и археологии Волго-Камья и соответствуют общим направлениям научноисследовательской деятельности Института.

Важным направлением научной политики Института является интеграция в глобальное образовательное пространство, создание современных образовательных продуктов и программ по международному академическому обмену. Восемь сотрудников Института ведут преподавательскую деятельность в Казанском (Приволжском) федеральном университете (далее - КФУ) в рамках профиля «Археология». Реализация этой стратегии нашла отражение в проведенной совместно с КФУ в отчетном году Итоговой международной научной конференции Института археологии им. А.Х. Халикова Академии наук Республики Татарстан. В работе конференции приняли участие 58 учёных-археологов, помимо сотрудников Института, это исследователи, представляющие научные центры Российской Федерации (Астрахань, Самара, Тольятти, Томск, Чебоксары) и дальнего зару-

Рис. 8. Программа Итоговой конференции Института археологии АН РТ 2020 г.

Fig. 8. Program of the Final Conference of the Institute of Archaeology of the Tatarstan Academy of Sciences in 2020
Рис. 7. Раскопки Болгарского городища в 2020 г.

Fig. 7. Excavations at the Bolgar fortified settlement in 2020.

бежья (Германия, Монголия), активно сотрудничающие с археологами Татарстана (рис. 8).

Совместно с КФУ проводится ежегодное научно-образовательное мероприятие - Международная археологическая школа в Болгаре. Целью организации школы является консолидация отечественных и зарубежных научных и образовательных ресурсов для внедрения новейших достижений мировой науки в практику изучения и сохранения историко-культурного наследия народов Евразии. Школа ориентирована на потребности молодых учёных в знакомстве с новыми методами, представлении актуальных данных и коллаборации. В 2020 году VII Международная Болгарская археологическая школа прошла в формате онлайн-конференции на площадке платформы Teams. Участники имели возможность представить свои уникальные творческие проекты, обсудить их, получить экспертную оценку. В ходе работы конференции были организованы секции по следующим научным направлениям: «Археометаллургия», «Археозоология», «Методы комплексных археологических исследований в изучении взаимодействия человека и окружающей среды», «Палеоантропология», «Языковая археология». В работе школы участвовали 79 человек из 5 стран мира: США, Турции, Беларуси, Индии и России. По итогам работы VII Международной археологической школы участникам были предоставлены сертификаты и возможность публикации в очередном номере рецензируемого журнала «Археология евразийских степей».

Ключевым направлением научно-исследовательской деятельности Института является издание журналов «Поволжская археология»

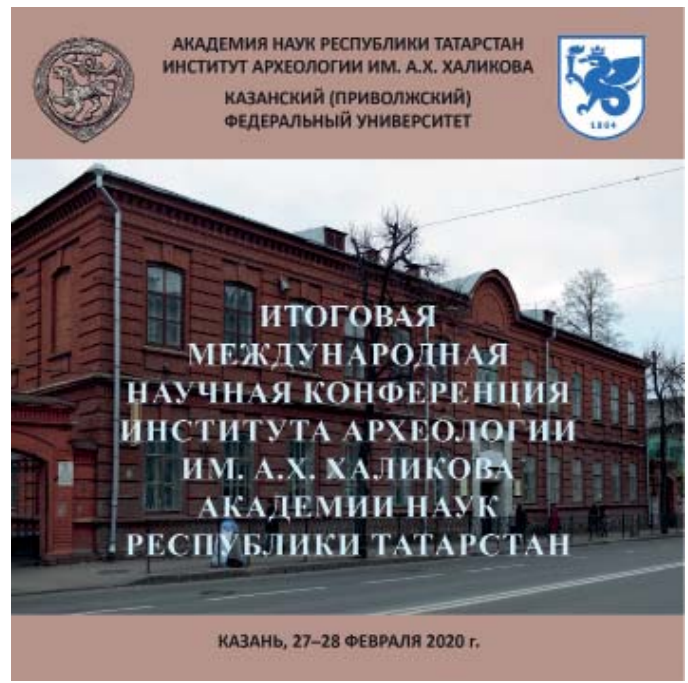



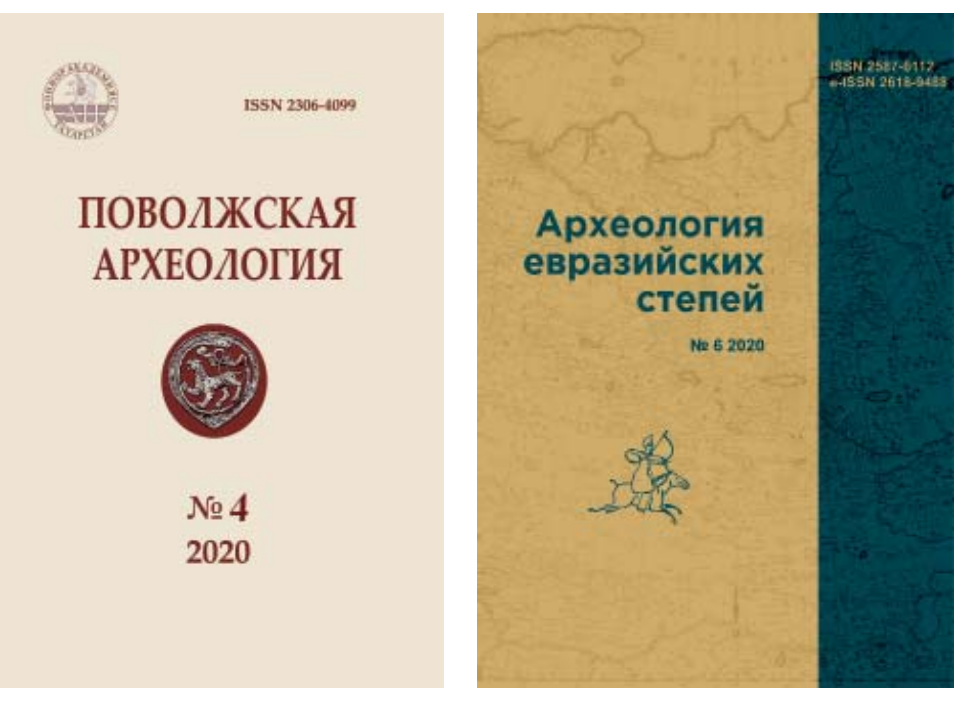

Рис. 9. Журналы, издаваемые Институтом археологии им. А.Х. Халикова

Fig. 9. Journals published by the Institute of Archaeology named after A. Kh. Khalikov (индексируется в SCOPUS, BAK) и «Археология Евразийских степей» (индексируется в ВАК). На страницах журнала «Поволжская археология» нашли отражение многоаспектные исследования в области изучения евразийских древностей в самом широком временном и территориальном диапазоне. В отчетном году было издано 4 номера журнала, в котором опубликовано 72 статьи общим объемом 62,4 а.л. Международный научный журнал «Археология Евразийских степей» (AEC) - один из научных приоритетов Института. Приоритетными задачами издания являются публикации результатов археологических исследований, в числе которых комплекс археологических и естественнонаучных, а также актуальных историографических материалов. В отчётном году издано 6 номеров журнала, в котором опубликовано 72 статьи и 4 монографии общим объемом 100 а.л. (рис. 9).

В 2020 г. сотрудники Института были удостоены различных республиканских наград, что является высокой оценкой научной деятельности Института. Указом Президента Республики Татарстан P.М. Минниханова начальнику Института Ситдикову А.Г. и заместителю начальника по научной работе Хайрутдинову Р.Р. присуждена государственная премия Республики Татарстан в области науки и техники за цикл работ по междисциплинарным исследованиям и сохранение памятников мирового историко-культурного наследия на примере объектов Свияжска и
Болгарского городища. Заведующий отделом средневековой археологии Измайлов И.Л. награжден Почетной грамотой Министерства образования и науки РТ. Старший научный сотрудник отдела первобытной археологии Чижевский А.А. поощрен Благодарственным письмом Министерства образования и науки РТ. Старший научный сотрудник отдела средневековой археологии Храмченкова Р.Х. поощрена Благодарственным письмом Президента Академии наук Республики Татарстан.

Уровень выполнения научно-исследовательской работы в отчетном году соответствует уровню ведущих российских научных центров и научных школ (г. Москва, г. СанктПетербург, г. Новосибирск). В предстоящем 2021 году представляется важным и целесообразным направить основные усилия ученых Института на дальнейшую организацию работы междисциплинарных исследовательских коллективов по завершению приоритетных научных проблем в рамках «Стратегии развития Института археологии им. А.Х. Халикова АН РТ на 2019-2021 гг.», а также на координацию региональных авторских коллективов по завершению подготовки к изданию томов многотомного издания «Археология ВолгоУральского региона». Не менее актуальным остается продолжение комплексных, охранно-спасательных исследований, камерального изучения артефактов и создание культурнохронологических схем, отвечающих современным требованиям археологической науки.

\section{ПУБЛИКАЦИИ ИНСТИТУТА}

\section{Монографии, научно-справочные издания, учебные пособия:}

Белорыбкин Г.Н., Гусынин В.А., Измайлов И.Л. Вооружение населения юго-западной Булгарии (X середина XIII века) / Археология Евразийских степей. 2020. № 1.354 с. 
Валиев Р.Р., Зеленеев Ю.А., Пигарев Е.М., Ситдиков А.Г. Селитренное городище: материалы исследований 2006, 2007, 2009 годов (берег р. Ахтубы). / Материалы и исследования по археологии Поволжья. Вып. 12. Йошкар-Ола: Марийский гос. ун-т, 2019. 424 с.

Ситдиков А.Г., Деденева А.А., Воробьева Е.Е. Научные принципы и методы реставрации и консервации бумаги: учебно-методическое пособие. Казань: Изд-во Казан.ун-та, 2020. 60 с.

Ситдиков А.Г., Измайлов И.Л., Шакиров 3.Г. Академия наук Республики Татарстан. Институт археологии им. А.Х. Халикова. Казань: АН РТ, 2019. 31 с.: илл.

Федоров-Давыдов Г.А., Мухаметиин Д.Г. Каратунский клад джучидских монет XIV века. Т. 1. 2-е изд., перераб. Казань: Изд-во Orange Key, 2020. 384 с.

Федоров-Давыдов Г.А., Мухаметшин Д.Г. Каратунский клад джучидских монет XIV века. Т. II. Казань: Изд-во Orange Key, 2020. 487 с.

Чижевский А.А., Хисяметдинова А.А. Оборонительные сооружения мысовых городищ Волго-Камья в раннем железном веке и раннем средневековье / Археология Евразийских степей. 2020. № 2. 277c.

\section{Cmambu:}

1. Абдуллин X.M. Два плана Татарской слободы Казани середины XVIII века из Российского государственного архива древних актов // Историческая этнология. 2019. Т. 4. № 2. С. 339-353.

2. Абдуллин Х.М. Сведения о представителях мусульманского военного духовенства в книге Ш. Марджани «Мустафад аль-ахбар фи ахваль Казан ва Булгар» // Мусульманин на службе Российской империи (к 200-летию Мирсалиха Бекчурина). Сб. статей по материалам Международной научно-практической конференции (Уфа, 28 мая 2020 г.). Уфа: Мир печати, 2020. С. 88-95.

3. Абдуллин Х.М., Беляев А.В., Сайфутдинова Г.М., Ситдиков А.Г. Археологические разведки на средневековом мусульманском кладбище слободы Биш-Балта в Казани // Археологические открытия. 2017 год / Отв. ред. Н. В. Лопатин. М.: Институт археологии РАН, 2019. С. 334-335.

4. Абдуллин Х.М., Галимуллина Г.Х., Насибуллина А.Б. Татарстан районнары торак пунктлары археология истәлекләрен өйрәнүнең кайбер нәтижәләре (Хәерби авылы мисалында) // Научный Татарстан. 2020. № 3. C. 57-63.

5. Абдуллин Х.М., Измайлов И.Л. Невозможность диалога: переписка Б. Шпулера и О. Прицака с казанскими историками-тюркологами // Східний світ = The World or the Orient. 2019. № 4. С. 5-26.

6. Абдуллин Х.М., Измайлов И.Л. Письмо Б. Шпулера и О. Прицака к казанским историкам-тюркологам по проблемам языка эпиграфических памятников Поволжья XIII-XIV вв. // Гасырлар авазы - Эхо веков. 2019. № 4. С. 127-143.

7. Абдуллин Х.М., Сайфутдинова Г.М., Ситдиков А.Г. Определение исторических границ поселения по данным картографических источников (на примере города Буинск Республики Татарстан) // Геодезия и картография. 2020. № 8. (в печати).

8. Асылгараева Г.Ш., Иожииа Д.В. Список научных работ Бочарова Сергея Геннадиевича // Поволжская археология. 2020. № 2 (32). С. 18-31.

9. Ахметгалин Ф.А., Ситдиков А.Г. Историческая топография Ханской столицы г. Касимова // Поволжская археология. 2020. № 2. С. 130-145.

10. Бадеев Д.Ю., Худяков А.В., Шакиров 3.Г. Археологические исследования на территории Билярского комплекса в 2016-2017 гг. // Археологические открытия. 2017 год / Отв. ред. Н.В. Лопатин. М.: Институт археологии РАН, 2019. С. 331-334.

11. Байтанаев Б.А., Петров П.Н., Шайхутдинова Е.Ф. Квантитативный анализ монетного серебра денежной реформы хана Кепека методом ОЭСА // Археология Казахстана. 2020. № 3 (9). С. 107-121.

12. Байтанаев Б.А., Петров П.Н., Шайхутдинова Е.Ф. Монетная реформа Кепек хана в свете результатов исследования состава монетного серебра методом РФА // Поволжская археология. 2019. № 4 (30). C. 43-54.

13. Бакиров Б.А., Кичанов С.Е., Храмченкова Р.Х., Белушкин А.В., Козленко Д.П., Ситдиков А.Г. Исследования монет средневековой Волжской Болгарии методами нейтронной дифракции и томографии // Поверхность. Рентгеновские, синхронные и нейтронные исследования. 2020. № 4. С. 69-75.

14. Баранов В.С. К вопросу об изучении исторической топографии Болгарского городища // Сборник материалов Всероссийской научно-практической конференции «Великий Болгар - цивилизация на Волге» / Ред. Г.М. Бирюкова, Д.Г. Мухаметшин, А.Н. Фасхутдинов. Ульяновск: ООО «Издательство «Корпорация технологий продвижения», 2020. С 131-141.

15. Баранов В.С., Измайлов И.Л. К вопросу об атрибуции перстня из раскопок в Болгаре 2010 года // Археология Евразийских степей. 2019. № 6. С. 260-276. 
16. Бахматова В.Н., Набиуллин Н.Г. Об использовании незапесоченных глин в гончарстве населения Среднего Поволжья X - XV вв. // Вестник «История керамики». Вып.2. / Отв. ред. Ю.Б. Цетлин М.: ИА РАН. 2020, С. 126-150.

17. Беляев А.В., Абдуллин Х.М., Сайфутдинова Г.М., Ситдиков А.Г. Археологические и междисциплинарные исследования средневекового мусульманского кладбища «Биш-Балта» Адмиралтейской слободы Казани в 2017 г. // Археология Евразийских степей. 2019. № 6. С. 230-245.

18. Беляев А.В., Абдуллин Х.М., Сайфутдинова Г.М., Ситдиков А.Г. Археологические разведки на средневековом мусульманском кладбище слободы «Биш-Балта» в Казани // Археологические открытия. 2017 год / Отв. Ред. Н. В. Лопатин. - М.: Институт археологии РАН, 2019. С. 334-335.

19. Беляев А.В., Епифанов Д.С., Садриев Н.Р., Старков А.С., Хасанов Д.Р. Археологические исследования на территории Казанского Богородицкого монастыря // Археологические открытия 2017 года / Отв. ред. Н. В. Лопатин. М.: ИА РАН. С. 335-337.

20. Березина Н.С., Березин А.Ю., Галимова М.Ш., Гольева А.А. Новые данные исследований стоянки финального палеолита Шолма I на Средней Волге (результаты раскопок 2017 и датирования) // Восточная Европа, Кавказ, Ближний Восток в каменном веке: хронология, источники и культурогенез. Международная конференция к 70-летию Х.А. Амирханова. Тезисы докладов. М.: ИА РАН, 2020. С. $18-19$.

21. Бочаров С.Г., Ситдиков А.Г., Асылгараева Г.Ш. Общие сведения о научной деятельности Института археологии им. А.Х. Халикова Академии наук Татарстана в 2019 году // Поволжская археология. 2020. № 1(31). С. 197-216.

22. Бугарчев А.И. О метрологии медных булгарских монет XIII в. из Джукетау (Татарстан) // На пути открытий в жизни и науке: сборник научных статей и воспоминаний к юбилею ученых-археологов Иванова Владимира Александровича и Обыденновой Гюльнары Талгатовны / Отв.ред. А. И. Кортунов. Уфа: БГПУ им. М.Акмуллы, 2020. С. 14-19.

23. Бугарчев А.И. О метрологии медных монет Сарая, Сарая ал-Джадида и Гулистана в XIV в. // Археология Казахстана. 2020. № 1(7). С. 98-114.

24. Бугарчев А.И., Емельянов В.П., Степанов О.В. Находки хаджитарханских монет на территории Татарстана // Астраханские краеведческие чтения. Вып. ХІІ. / Под ред. А.А. Куратова, А.Н. Алиевой. Астрахань: Издатель: Сорокин Роман Васильевич, 2020. С. 77-82.

25. Бугарчев А.И., Купщов А.Е. Второй клад джучидских монет XIII в. из Кайбицкого района РТ // Золотоордынское наследие. Материалы VI Международного Золотоордынского Форума «Рax Tatarica: генезис и наследие государственности Золотой Орды». (Казань, 26-28 июня 2019 г. ). Вып. 3. / Отв. ред. Э.Г. Сайфетдинова. Казань: Институт истории им. Ш. Марджани АН РТ, 2019. С. 99-107.

26. Бугарчев А.И., Купщов А.Е. Комплекс булгарских монет конца XIII - начала XIV в. из Старомайнского района Ульяновской области // Средневековая нумизматика Восточной Европы. Вып. 8 / Отв. ред. В.В. Зайцев. СПб.: ООО Контраст, 2020. С. 158-167.

27. Бугарчев А.И., Петров П.Н., Сингатуллина А.З., Шайхутдинова Е.Ф. Монеты хана Тимура из Измериевского клада // История и культура Великой степи. Материалы Международной научно-практической конференции / Под ред. М.Х. Абусеитовой. Алматы: «Шығыс пен Батыс», 2020. С. 142-145.

28. Бугарчев А.И., Степанов О.В. Археологические и нумизматические находки из Алькеевского района РТ // Родной край. 2020. № 1. С. 77-81.

29. Бугарчев А.И., Степанов О.В. Два клада булгарских монет начала XV в. из Атнинского района Татарстана // Родной край. 2020. № 3-4. С. 124-127.

30. Бугарчев А.И., Степанов О.В. Монетные находки из Новошешминского района РТ // Родной край. 2020. № 2. С. 107-108.

31. Бугарчев А.И., Степанов О.В. Находки джучидских серебряных монет XV в. на территории Иски-Казанского археологического комплекса // Золотоордынское наследие. Материалы VI Международного Золотоордынского Форума «Рах Tatarica: генезис и наследие государственности Золотой Орды». (Казань, 26-28 июня 2019 г. ). Вып. 3. / Отв. ред. Э.Г. Сайфетдинова. Казань: Институт истории им. Ш. Марджани АН РТ, 2019. С. 211-216.

32. Бугарчев А.И., Степанов О.В. О находке клада булгарских монет второй четверти XV в. из Ульяновской области // Нумизматические чтения Государственного Исторического музея 2019 года (Москва, 26 и 27 ноября 2019 года) / Отв. ред. Е.В. Захаров. М.: ГИМ, 2019. С. 88-92.

33. Бугарчев А.И., Степанов О.В., Емельянов В.П. Монеты XIV в. из окрестностей деревни Ржавец (Спасский район Республики Татарстан) // Человек и природа в бассейне реки Ик в историческом развитии. Вклад населенных пунктов Азнакаевского района, Юго-Восточного и Восточного Татарстана в развитии экономики и культуры Татарской АССР и татарского народа. Материалы Всероссийской 
конференции. Серия «Восток - Запад: диалог культур и цивилизаций Евразии». Вып. 21 / Под ред. А.А. Бурханова. Казань: Отечество, 2020. С. 27-30.

34. Бугров Д.Г., Асылгараева Г.Ш. Животные в погребальном обряде населения Нижнего Прикамья первой половины I тыс. н.э. (по материалам Гулюковского могильника) // Поволжская археология. 2020. № 1 (31). C. 146-166.

35. Валеев Р.М., Хайрутдинов Р.Р, Нефедьев Ю.А., Ситдиков А.Г, Валеева-Хакимова Р.Р. Астрономические обсерватории Казанского университета как потенциальный объект Всемирного культурного наследия ЮНЕСКО // Наследие и современность. 2020. Т.3. № 1. С. 30-53.

36. Валиев P.P. Разведочные исследования на Новославском II могильнике в 2018 г. // Сборник материалов Всероссийской научно-практической конференции «Великий Болгар - цивилизация на Волге» / Ред. Г.М. Бирюкова, Д.Г. Мухаметшин, А.Н. Фасхутдинов. Ульяновск: ООО «Издательство «Корпорация технологий продвижения», 2020. С. 120-130.

37. Вафина Г.X. Трехмерная визуализация образцов керна слоистых отложений методом фотограмметрии. // Материалы Международного молодежного научного форума «ЛОМОНОСОВ-2020» / Отв. ред. И.А. Алешковский, А.В. Андриянов, Е.А. Антипов. М.: МАКС Пресс, 2020. Доступно по:: https:// lomonosov-msu.ru/archive/Lomonosov_2020/index.htm, (дата обращения 23.01.2021).

38. Вафина Г.Х., Овечкина Л.В. Фотограмметрия как средство сохранения и изучения объектов культурного наследия // IX Научно-практическая конференция «Актуальные в опросы геодезии и геоинформационных систем» (Казань, 2-3 сентября, 2020). Казань: Изд-во Казанского университета, 2020. C. 37-42.

39. Волкова Е.В., Куфтерин В.В. Население пьяноборской культуры Нижнего Прикамья по данным остеометрии (материалы могильника Старый Чекмак) // Поволжская археология. 2020. № 1. С. 23-35.

40. Волкова E.B., Саттаров P.P. Раскопки городища Манчиха в 2019 году // Археологические открытия в Самарской области 2019 года / Отв. ред. Д.А. Сташенков. Самара: Изд-во СОИКМ, 2020. C. 24.

41. Вязов Л.А., Михайлов Е.П., Макарова Е.М., Мясникова А.Б., Мясников Н.С., Петрова Д.А., Салова Ю.А., Силанов Р.А. Исследования памятников Среднего и Нижнего Посурья в рамках работы международной археологической экспедиции в 2015-2019 гг. // Археология Евразийских степей 2020. № 3. C. 354-373.

42. Вязов Л.А., Пономаренко Е.В., Ершова Е.Г., Салова Ю.А. Между подсекой и пахотой: применение рыхлящих орудий в исторических системах земледелия Восточной Европы и его следы в почве // Экология древних и традиционных обществ Вып. 6. Материалы VI Международной научной конференции (Тюмень, 2-6 ноября 2020 г.) / Отв. ред. Н.П. Матвеева, Н.Е. Рябогина. Тюмень: Изд-во ТюмНЦ СО $\mathrm{PAH}, 2020$. C. 143-149.

43. Галимова М.Ш., Сташенков Д.А., Кочкина А.Ф. Предварительные результаты функционального анализа каменного инвентаря стоянки Гора Маяк в Среднем Поволжье // Археология Евразийских степей. 2020. № 3. С. 317-322.

44. Голубева Е.Н., Чижевский А.А. Каменный инвентарь энеолитических погребений Мурзихинского II могильника // Археология Евразийских степей. 2020. № 3. С. 275-284.

45. Голубева Е.Н., Чижевский А.А. Сланцевые подвески из энеолитических погребений Мурзихинского II могильника: морфолого-функциональный анализ (предварительные данные) // Археология Евразийских степей. 2020. № 5. С. 76-88.

46. Губайдуллин А.М, Хамзин Р.Н. Археологические исследования по ул. Калинина в г. Казани в 2019 г. // Археологические открытия. 2019 год (в печати).

47. Губайдуллин А.М. О булгарских городищах Западного Закамья // Археология Евразийских степей. 2019. № 6. С. 252-259.

48. Губайдуллин А.М. О крепостных сооружениях городищ Западного Предволжья // Археология Евразийских степей. 2020. № 1. С. 205-216.

49. Губайдуллин А.М. О музеефикации объектов фортификации // Археология Евразийских степей. 2019. № 5. C. 81-82.

50. Губайдуллина А.В. Каменные украшения с Болгарского городища в собрании А.Ф. Лихачева // Сборник материалов Всероссийской научно-практической конференции «Великий Болгар - цивилизация на Волге» / Ред. Г.М. Бирюкова, Д.Г. Мухаметшин, А.Н. Фасхутдинов. Ульяновск: ООО «Издательство «Корпорация технологий продвижения», 2020. С. 95-109.

51. Емельянов В.П., Бугарчев А.И. Джучидские монеты из Джукетау (новые материалы) // Нумизматические чтения Государственного Исторического музея 2019 года (Москва, 26-27 ноября 2019 г.). / Отв. ред. Е.В. Захаров. М.: ГИМ, 2019. С. 74-77. 
52. Ермошин А.В., Мустафина Г.М. Выпускник Казанской духовной академии Михаил Григорьевич Васильев: жизнь и судьба // Известия по Казанской епархии. 2020. № 3. С. 64-77.

53. Зоря. Р.С. Находка деталей поясного набора из раскопа СХСІХ Болгарского городища // Поволжская археология. 2020. № 2 (32). С. 217-225.

54. Измайлов И.Л. Булгарская археологическая культура: структура и содержание понятия // Археология Евразийских степей. 2019. № 6. С. 198-222.

55. Измайлов И.Л. Происхождение и начальный этап этнокультурной истории тюркских народов (к постановке проблемы) // Северо-Восточный гуманитарный вестник. 2019. № 4(29). С. 47-63.

56. Измайлов И.Л., Рахматуллина Ч.3. Великий Шелковый путь и города Среднего Поволжья в XIII-XV вв.: предыстория Чайного пути // The international conference. The Tea Road and Nomads. (18-19th October 2019). Ulaanbaator: "Erdenezul" Printing Press, 2019. p. 15-30.

57. Карпухин С.В., Буршнева С.Г., Багаутдинов А.Р. Мониторинг состояния сохранности и противоаварийная консервация музейных археологических коллекций. Первый опыт // Коллоквиум молодых реставраторов RESCON-2019: материалы Всероссийской научно-практической молодежной конференции (Казань, 25-27 ноября 2019 г.) / науч. ред. С.Г. Буршнева. Казань: Издательство Казанского университета, 2019. С. 10-13.

58. Красильников П.В. Археологические разведки в Приволжском районе г. Казани в 2019 году // Археологические открытия. 2019 год (в печати).

59. Красильников П.В. Археологические раскопки на территории Сабакайкинского I селища (XI-XIV вв. н.э.) в Алексеевском районе Республики Татарстан в 2019 году // Археологические открытия. 2019 год (в печати).

60. Куклина А.А. Новые исследования общеболгарской керамики: историко-культурный подход // Поволжская археология. 2020. № 2(32). С. 228-237.

61. Лыганов А.В. Археологические исследования Курманаковской IV стоянки // Археологические открытия 2017 года / Отв. ред. Н. В. Лопатин. М.: Институт археологии РАН, 2019. С. 339-340.

62. Лыганов А.В. К вопросу о культурно-хронологической принадлежности двух могильников позднего бронзового века в Волго-Камье (из раскопок А.Х. Халикова) // Поволжская археология. 2020. № 3(33). C. 144-158.

63. Лыганов А.В. Мальцевская IV стоянка позднего бронзового века на р. Тойма в Нижнем Прикамье // Археология Евразийских степей. 2020. № 5. С. 182-197.

64. Лыганов А.В., Морозов В.В., Смирнов А.Л., Хуснутдинов Э.А., Бакаев С.Е. Находки изделий ананьинской культурно-исторической области на территории могильника и селища Такталачук в нижнем течении р. Белой // Археология Евразийских степей. 2020. № 2. С. 318-323.

65. Лыганов А.В., Хамзин Р.Н., Оруджов Э.И. Археологические исследования на Куйбышевском водохранилище // Археологические открытия 2017 года / Отв. ред. Н.В. Лопатин. М.: Институт археологии РАН, 2019. С. 341-344.

66. Мустафина Г.М. «Пруссаки никогда не забудут пребывания наших войск в их земле...» (фронтовые письма А. М. Ременникова) // Гасырлар авазы - Эхо веков. 2020. № 2. С. 41-50.

67. Мухаметшина А.С., Садриев Н.Р., Шелковская О.Е. К истории формирования археологических коллекций собрания Музея-заповедника «Казанский кремль» / Научно-исследовательская работа в музее. Музейный предмет и научно-исследовательская работа музея. Комплектование. Изучение. Использование. Авторские статьи заочной конференции 2020 года, проведенной ФДПО МГИК и ДИХМ / Науч. ред. и сост. Н. И. Решетников. М.: Изд-во ЭПИ «Открытый текст», 2020. Доступно по: URL http://opentextnn.ru/wp-content/uploads/nir2020.pdf (дата обращения 23.01.2021)

68. Набиуллин Н.Г. Из истории формирования коллекций Джукетау / Материалы Всероссийского научно-практического семинара «Археолог и музей: диалог о вечном». Казань, 11-13 сентября 2019 г. // Археология Евразийских степей. 2019. № 5. С. 24-30.

69. Нуретдинова А.Р., Хузин Ф.Ш. К юбилею Светланы Игоревны Валиулиной // Поволжская археология. 2020. № 1 (31). С. 234-238.

70. Овечкина Л.В. Геопортал «Культурное наследие Татарстана и татарского народа» как форма интеграции результатов археологических исследований // Материалы Международного молодежного научного форума «ЛОМОНОСОВ-2020» / Отв. ред. И.А. Алешковский, А.В. Андриянов, Е.А. Антипов М.: МАКС Пресс, 2020. Доступно по: https://lomonosov-msu.ru/archive/Lomonosov_2020/index.htm (дата обращения 23.01.2021).

71. Оруджов Э.И. Чижевское городище. Предварительные результаты исследований 2019 // Археологические открытия Кировской области - 2019 г. / Отв. ред. А.О. Кайсин. Киров: Изд-во ВятГУ, 2020. C. $10-15$. 
72. Оруджсв Э.И., Кайсин А.О. Топографические и культурно-хронологические аспекты в изучении Чижевского городища // Поволжская археология. 2020. № 3 (33). С. 196-207.

73. Очир-Горяева М.А. Поза всадника по археологическим и этнографическим данным // Oriental Studies. 2019. № 5. C. 812-821.

74. Пашина E.B. Институт воеводства в Тетюшах в последней трети XVI - XVII вв.: численность, состав, управление // Учен. зап. Казан. ун-та. Сер. Гуманит. науки. 2020. Т. 162, кн. 1. С. 23-34.

75. Пашина E.B. Особенности развития города-крепости Тетюши в последней трети XVI - XVII вв. (к постановке вопроса) // Политические, социально-экономические и межэтнические процессы в пограничных регионах России в XVI - начале XX вв.: материалы международной научно-практической конференции (г. Уфа, 1-4 июня 2020 г.) / Отв. ред. Р.Г. Буканова. Уфа: Мир печати, 2020. С. 23-34.

76. Перевозчикова С.А., Кузьминых С.В., Чижевский А.А. «Покой мне только снится»: к юбилею Е.M. Черных // Поволжская археология. 2020. № 1(31). С. 227-233.

77. Пономаренко Е.В., Ершова Е.Г., Вязов Л.А., Блинников М.С. Подсека - от Сибири до Канады // Экология древних и традиционных обществ Вып. 6. Материалы VI Международной научной конференции (Тюмень, 2-6 ноября 2020 г. ) / Отв. ред. Н.П. Матвеева, Н.Е. Рябогина. Тюмень: Изд-во ТюмНЦ СО PAH, 2020. C. 149-153.

78. Пудикова М.С., Буршнева С.Г., Шайхутдинова Е.Ф Использование восстановительных свойств ультразвука для получения новых данных при реставрации железных археологических предметов // Коллоквиум молодых реставраторов RESCON-2019: материалы Всероссийской научно-практической молодежной конференции (Казань, 25-27 ноября 2019 г.) / науч. ред. С.Г. Буршнева. Казань: Изд-во КГУ, 2019. С. 85-90.

79. Саттаров Р.P. Мужской головной убор из Кипчаковского II могильника пьяноборской культуры // Вопросы археологии Поволжья. Вып. 8 / Отв. ред. М.А. Турецкий. Самара: Слово, 2020. C. 208-217.

80. Саттаров Р.P. Результаты исследований Кипчаковского II могильника пьяноборской культуры в Икско-Бельском междуречье в 2015 году // Археология Евразийских степей. 2020. № 5. С. 104-118.

81. Саттаров Р.P., Денисов А.В. Археологические разведки в Шигонском районе Самарской области в 2019 году // Археологические открытия в Самарской области 2019 года / Отв. ред. Д.А. Сташенков. Самара: Изд-во СОИКМ, 2020. С. 41-42.

82. Саттаров Р.P., Денисов А.В. Селище Озеро Белое I - новый памятник археологии в Волжском районе Самарской области // Археологические открытия в Самарской области 2019 года / Отв. ред. Д.А. Сташенков. Самара: Изд-во СОИКМ, 2020. С. 22-23.

83. Саттаров Р.P., Доткин К.В. Изделия из цветных металлов и сплавов Кипчаковского II могильника пьяноборской культуры // Археология Евразийских степей. 2020. № 5. С. 119-129.

84. Ситдиков А.Г. Открытия в городе - музее // Казань. 2020. № 3. С. 30-35.

85. Ситдиков А.Г. Чем порадовал археологов остров-град Свияжск // Казань. 2020. № 3. С. 78-81.

86. Ситдиков А.Г., Базаров Б.А., Гомбожапов А.Д., Нолев Е.В., Красильников П.В. IV Международный конгресс средневековой археологии евразийских степей // Поволжская археология. 2020. № 1 (31). C. 217-226.

87. Ситдиков А.Г., Базаров Б.А., Гомбожапов А.Д., Нолев Е.В., Красильников П.В. О работе IV Международного конгресса средневековой археологии евразийских степей, посвященного 100-летию Российской академической археологии» // Археология Казахстана. 2019. № 4 (6). С. 154-161.

88. Ситдиков А.Г., Красильников П.В., Базаров Б.А., Гомбожапов А.Д., Нолев Е.В. IV Международный конгресс археологии евразийских степей // РА. 2020. № 3. С. 204-205.

89. Степанов О.В., Бугарчев А.И. О кладе ордынских монет XIV в. из окрестностей г. Тольятти (Самарская область) // Татарские населенные пункты: история, современность и перспективы развития (городская слобода и сельское поселении). Материалы Всероссийского форума татарских краеведов / «Восток-Запад: диалог культур и цивилизаций Евразии». Вып. 20 / Под ред. А.А. Бурханова. Казань: Отечество, 2020. С. 191-194.

90. Федан П.В., Садриев Н.Р. К вопросам об атрибуции изделий из свинца, по материалам раскопа «Татарская слободка», город Свияжск // Коллоквиум молодых реставраторов RESCON-2019: материалы Всероссийской научно-практической молодежной конференции (Казань, 25-27 ноября 2019 г.) / науч. ред. С.Г. Буршнева. Казань: Издательство Казанского университета, С. 94-98.

91. Федан П.В., Храмченкова Р.Х, Мухаметиин Д.Г, Ситдиков А.Г. Химический состав серебряных монет второй половины XIV- первой трети XV в., имеющих хождение в Болгарском улусе // Археология Евразийских степей. 2020. № 5. С. 214-226. 
92. Хазиев А.И., Шигапов М.Б. Археологические исследования в г. Казани // Археологические открытия. 2017 год / Отв. ред. Н. В. Лопатин. М.: Институт археологии РАН, 2019. С. 344.

93. Хамзин Р.Н. История археологического изучения памятников бассейна р. Свияги $\mathrm{X}-\mathrm{XV}$ вв. // Сборник материалов Всероссийской научно-практической конференции «Великий Болгар - цивилизация на Волге» / Ред. Г.М. Бирюкова, Д.Г. Мухаметшин, А.Н. Фасхутдинов. Ульяновск: ООО «Издательство «Корпорация технологий продвижения», 2020. С. 348-355.

94. Храмченкова Р.Х., Бакиров Б.А., Кичанов С.Е., Белушкин А.В., Козленко Д.П., Ситдиков А.Г. Исследования монет средневековой Волжской Болгарии методами нейтронной дифракции и томографии // Поверхность. Рентгеновские, синхротронные и нейтронные исследования. 2020. № 4. С. 69-75.

95. Храмченкова Р.Х., Каплан П.Ю., Ситдиков А.Г., Гареев Б.И., Баталин Г.А. Неразрушающий рентгенофлуоресцентный метод исследования фресковой росписи как инструмент мониторинга процессов деградации левкаса // Декоративное искусство и предметно-пространственная среда. Вестник МГХПА. 2019. № 3-1. С. 79-88.

96. Худяков А.В., Абдуллин Х.М., Хузин Ф.Ш., Шакиров З.Г. Археологические разведки в окрестностях Билярска // Археологические открытия 2019 г. (в печати).

97. Худяков А.В., Набиуллин Н.Г., Шакиров 3.Г., Шорохов М.В. Археологические раскопки на территории Билярского городища и Балынгузского кладбища в 2018-2019 гг.// Археологические открытия. 2019 год (в печати).

98. Хузин Ф.Ш. Старейшина татарской археологии (к 85-летию Е.П. Казакова) // Археология Евразийских степей. 2019. № 6. С. 47-52.

99. Хузин Ф.Ш., Хасанов Д.Р., Хамзин Р.Н. Археологические исследования по ул. Петербургская 55/5 в г. Казани в 2019 г. // Археологические открытия. 2019 год (в печати).

100. Хузин Ф., Шакиров 3. Жизнь и труды профессора Альфреда Халикова (к 90-летию выдающегося татарского археолога) // Приноси към българската археология (Contributions To Bulgarian Archaeology). 2019. T. IX C. 191-201.

101. Чижевский A.A. Евгений Петрович Казаков и археология ананьинской культурно-исторической области // Археология Евразийских степей. 2019. №6. С. 28-41.

102. Чижевский А.А., Гисматулин М.Р., Храмченкова Р.Х. Бронзовый чекан из археологического собрания Ульяновского областного краеведческого музея им. И. А. Гончарова // Stratum plus. Археология и культурная антропология. 2019. № 3. С. 99-112.

103. Чижевский А.А., Голубева Е.Н. Погребение № 90 Мурзихинского II могильника. Трасологический анализ каменного инвентаря эпохи энеолита // Феномены культур бронзового века степной и лесостепной полосы Евразии: пути культурного взаимодействия в V-III тыс. до н.э. / Отв. ред. Н.Л. Моргунова. Оренбург: ОГПУ, 2019. С. 42-51.

104. Чижевский А.А., Нигамаев А.З., Храмченкова Р.Х. Комплекс предметов вооружения ананьинского времени из Танаевского леса // Поволжская археология. 2020. № 3(33). С. 181-195.

105. Шакиров 3.Г. Проблемы изучения и музеефикации археологизированных объектов Билярского городища // Археология Евразийских степей. 2019. № 5. С. 83-93.

106. Шакиров 3.Г., Худяков А.В., Набиуллин Н.Г. Новые исследования мусульманских погребальных памятников Билярского комплекса // Материалы X Международной тюркологической конференции «Тюркский мир: язык, литература, история и религия» (дата, место) (в печати).

107. Шакиров 3.Г., Шорохов М.В. Историко-археологические исследования погребальных памятников на горе Балынгуз // Сборник материалов Всероссийской научно-практической конференции «Великий Болгар - цивилизация на Волге» / Ред. Г.М. Бирюкова, Д.Г. Мухаметшин, А.Н. Фасхутдинов. Ульяновск: ООО «Издательство «Корпорация технологий продвижения», 2020. С. 260-276.

108. Bakirov B.A, Kichanov S.E, Khramchenkova R.K, Sitdikov A.G. Studies of Coins of Medieval Volga Bulgaria by Neutron Diffraction and Tomography // Journal of Surface Investigation. 2020. Vol.14, Is.2. P. 376-381.

109. Felix M. Key, Cosimo Posth, Luis R. Esquivel-Gomez, Ron Hübler1, Maria A. Spyrou, Gunnar U. Neumann, Anja Furtwdngler, Susanna Sabin, Marta Burril, Antje Wissgott, Aditya Kumar Lankapalli, Eshild J. Vegene, Matthias Meyer, Sarah Nagel, Rezeda Tukhbatova, Aleksandr Khokhlov, Andrey Chizhevsky, Svend Hansen, Andrey B. Belinsky, Alexey Kalmykov, Anatoly R. Kantorovich, Vladimir E. Maslov, Philipp W. Stockhammer, Stefania Vai, Monica Zavattaro, Alessandro Riga, David Caramelli, Robin Skeates, Jessica Beckett, Maria Giuseppina Gradoli, Noah Steuri, Albert Hafner, Marianne Ramstein, Inga Siebke, Sandra Lösch, Yilmaz Selim Erda, Nabil-Fareed Alikhan, Zhemin Zhou, Mark Achtman, Kirsten Bos, Sabine Reinhold, Wolfgang Haak, Denise Kühnert, Alexander Herbig and Johannes Krause. Emergence of human-adapted Salmonella enterica is linked to the Neolithization process // Nature ecology and evolution. 2020. No 4. P. 
324-333. (Доступно по URL: https://www.nature.com/articles/s41559-020-1106-9. (дата обращения: 22.01.2020).

110. Gubaidullin A., Usmanov B., Gainullin I., Bagautdinova L. Studying the state of Volga-Bulgarian fortified settlements under agricultural impact with the use of multi-time aerial and space imagery // International Multidisciplinary Scientific GeoConference-SGEM. Sofia, 2019. № 2.2. pp. 639-646

111. Kosareva, L.R., Kuzina, D.M., Nurgaliev, D.K., Sitdikov, A.G., Luneva, O.V., Khasanov, D.I., Suttie, N., Spassov, S. Archaeomagnetic investigations in Bolgar (Tatarstan)//Studia Geophysica et Geodaetica. 2020. Vol. 64, Is. 2. pp. 255-292.

112.Shaykhutdinova E., Belyaev A., Sitdikov A., Yanbaev R. The chemical and structural peculiarities of the Kazan Khanate cast-iron cookware in the 14th-15th centuries // 6th SWS International Scientific Conference on Arts and Humanities 2019 (Albena, Bulgaria, 26.08 - 01.09.2019) София: Общество с ограниченной ответственностью СТЕФ92 Технолоджи, 2019. С. 167-174.

113. Vladimir Napol'skich. Jukagirisch und Uralisch: Was bleibt übrig? [Юкагирский и уральский: что в остатке?] // Kīel joug om šīld. Festschrift zum 65. Geburtstag von Eberhard Winkler. Hrsg. von Hans-Hermann Bartens, Lars-Gunnar Larsson, Katja Mattsson, Judit Molnár und Tiina Savolainen / Veröffentlichungen der Societas Uralo-Altaica. Bd. 94. Wiesbaden 2020. S. 269-289.

\section{ЛИТЕРАТУРА}

Бочаров С.Г., Ситдиков А.Г., Асылгараева Г.Ш. Общие сведения о научной деятельности Института археологии им. А.Х. Халикова Академии наук Татарстана в 2019 году // Поволжская археология. 2020. № 1. C. 196-216.

Ситдиков А.Г., Каримов И.Р. Об основных итогах научной деятельности Института археологии им. А.Х. Халикова Академии наук Республики Татарстан в 2015 г. // Поволжская археология. 2016. № 1. C. 276-290.

Ситдиков А.Г., Каримов И.Р. Об основных итогах научной деятельности Института археологии им. А.Х. Халикова Академии Наук Татарстана в 2016 году // Поволжская археология. 2017. № 2. С. 330-343.

Ситдиков А.Г., Каримов И.Р., Асылгараева Г.Ш. Об основных итогах научной деятельности Института археологии им. А.Х. Халикова Академии Наук Татарстана в 2017 году // Поволжская археология. 2018. № 1. C. 342-354.

Ситдиков А.Г., Шакиров 3.Г., Каримов И.Р. Об основных итогах научной деятельности Института археологии им. А.Х. Халикова Академии наук Татарстана в 2014 году // Поволжская археология. 2015. № 1. C. 241-259.

Федоров-Давыдов Г.А., Мухаметшин Д.Г. Каратунский клад джучидских монет XIV века. Казань: Изд-во Orange Key, 2020. Т. 1. 384 с.

Федоров-Давыдов Г.А., Мухаметшин Д.Г. Каратунский клад джучидских монет XIV века. Казань: Изд-во Orange Кеу, 2020. Том II. 487 с.

Информационная географическая система «Культурное наследие Татарстана и татарского народа». 2020. Доступно по: URL: http://archtat.ru/kulturnoye_naslediye_tatarstana (дата обращения 25.12.2020)

\section{Информация об авторах:}

Ситдиков Айрат Габитович, доктор исторических наук, декан, Казанский (Приволжский) федеральный университет (г. Казань, Россия), начальник, Институт археологии им. А.Х. Халикова АН РТ (г. Казань, Россия); sitdikov_a@mail.ru

Саттаров Рузиль Раильевич, кандидат исторических наук, доцент, Казанский (Приволжский) федеральный университет (г. Казань, Россия), ученый секретарь, Институт археологии имени А.Х. Халикова Академии наук Республики Татарстан (г. Казань, Россия); sattarov.rr@rambler.ru

Асылгараева Гульшат Шарипзяновна, кандидат ветеринарных наук, старший научный сотрудник, Институт археологии им. А.Х. Халикова АН РТ (г. Казань, Россия); gul_shat@mail.ru

\section{REFERENCES}

Bocharov, S. G., Sitdikov, A. G., Asylgaraeva, G. Sh. 2020. In Povolzhskaya arkheologiya (Volga River Region Archaeology) 31 (1), 197-216 (in Russian).

Sitdikov, A. G., Karimov, I. R. 2016. In Povolzhskaya arkheologiya (Volga River Region Archaeology) 15 (1), 276-290 (in Russian). 
Sitdikov, A. G., Karimov, I. R. 2017. In Povolzhskaya arkheologiya (Volga River Region Archaeology) 20 (2), 330-343 (in Russian).

Sitdikov, A. G., Karimov, I. R., Asylgaraeva, G. Sh. 2018. In Povolzhskaya arkheologiya (Volga River Region Archaeology) 23 (1), 342-354 (in Russian).

Sitdikov, A. G., Shakirov, Z. G., Karimov, I. R. 2015. In Povolzhskaya arkheologiya (Volga River Region Archaeology) 11 (1), 241-259 (in Russian).

Fedorov-Davydov, G. A., Mukhametshin, J. G. 2020. Karatunskiy klad dzhuchidskikh monet XIV veka (The Karatun Hoard of Juchid Coins from 14th Century). Vol. 1. Kazan: "Orange Key" Publ. (in Russian).

Fedorov-Davydov, G. A., Mukhametshin, J. G. 2020. Karatunskiy klad dzhuchidskikh monet XIV veka (The Karatun Hoard of Juchid Coins from 14th Century). Vol. 2. Kazan: "Orange Key" Publ. (in Russian).

2020. Informatsionnaya geograficheskaya sistema «Kul'turnoe nasledie Tatarstana i tatarskogo naroda» (Cultural Heritage of Tatarstan and the Tatar People Information and Geography System) Available at: URL: http://archtat.ru/kulturnoye_naslediye_tatarstana (accessed 25.12.2020) (in Russian).

\section{About the Authors:}

Sitdikov Airat G. TAS Corresponding Member. Doctor of Historical Sciences. Head of department, Kazan (Volga Region) Federal University. Kremlyovskaya St., 18, Kazan, 420000, the Republic of Tatarstan, Russian Federation; Institute of Archaeology named after A. Kh. Khalikov, Tatarstan Academy of Sciences. Butlerov Str., 30, Kazan, 420012, the Republic of Tatarstan, Russian Federation; sitdikov_a@mail.ru

Sattarov Ruzil R. Candidate of Historical Sciences. Kazan (Volga Region) Federal University. Kremlyovskaya str., 18, Kazan, 420008, Republic of Tatarstan, Russian Federation; Institute of Archaeology named after A.Kh. Khalikov, Academy of Sciences of the Republic of Tatarstan. Butlerov St., 30, Kazan, 420012, Republic of Tatarstan, Russian Federation; sattarov.rr@rambler.ru

Asylgaraeva Gulshat Sh. Candidate of Veterinary Sciences. Institute of Archaeology named after A.Kh. Khalikov, Tatarstan Academy of Sciences. Butlerov St., 30, Kazan, 420012, Republic of Tatarstan, Russian Federation; gul_shat@mail.ru 